J. Math. and Its Appl.

E-ISSN: 2579-8936

P-ISSN: $1829-605 \mathrm{X}$

Vol. 15, No. 1, Maret 2018, 17-29

\title{
Perbandingan Metode Kalman Filter, Extended Kalman Filter, dan Ensemble Kalman Filter pada Model Penyebaran Virus HIV/AIDS
}

\author{
Agus N. A. Syarifudin ${ }^{1}$, Dian A. Merdekawati ${ }^{2}$, Erna Apriliani ${ }^{3}$ \\ 1,2,3 Institut Teknologi Sepuluh Nopember Surabaya \\ ${ }^{1,2,3}$ Departemen Matematika ITS Surabaya Indonesia \\ agusnuras2011@gmail.com ${ }^{1}$ \\ merdekawati.dianayu@gmail.com ${ }^{2}$ \\ aprilmath12@gmail.com ${ }^{3}$
}

\begin{abstract}
Abstrak
Pada paper ini akan dibahas mengenai perbandingan metode estimasi antara Kalman Filter, Extended Kalman Filter dan Ensemble Kalman Filter untuk mengestimasi tingkat penyebaran virus HIV/AIDS pada Gay. Digunakan persamaan $S, S_{g}, I, I_{g}$, dan $A$ pada persamaan untuk mengetahui tingkat penyebaran virus HIV pada orang yang rentan normal, rentan gay, terinfeksi normal, terinfeksi gay, dan populasi AIDS-nya. Dari beberapa simulasi yang dilakukan, dapat didapatkan hasil bahwa Metode Extended Kalman Filter juah lebih baik dibandingkan dengan kedua metode lainnya.
\end{abstract}

Kata Kunci: Kalman Filter, Extended Kalman Filter, Ensemble Kalman Filter, HIV/AIDS

\begin{abstract}
This paper presents a performance comparison of Kalman Filtering methods, such as Kalman Filter, Extended Kalman Filter, and Ensemble Kalman Filter to estimate HIV/AIDS' spreading level on gay population by denoting $S, S_{g}, I, I_{g}, A$ as normal susceptible, gay susceptible, normal infected, gay infected, and AIDS population, respectively. The results of numerical experiments provide that Extended Kalman Filter is the best estimator among the others.
\end{abstract}

Keywords: Kalman Filter, Extended Kalman Filter, Ensemble Kalman Filter, HIV/AIDS

\section{Pendahuluan}

Kalman Filter adalah suatu metode yang digunakan untuk melakukan estimasi suatu nilai. Kalman Filter atau Linier Least Mean Squares Estimator (LLSME) ini digunakan untuk meminimumkan error estimasi mean squared pada liniear stokastik menggunakan noisy linear sensors. Selain itu metode ini juga sering disebut Linear Quadratic Estimator (LQE) karena 
meminimumkan fungsi kuadratik dari error estimasi pada sebuah sistem dinamis linear dengan white measurement dan disturbance noise [1].

Kalman Filter ditujukan bagi permasalahan umum estimasi pada suatu keadaan dari proses kontrol diskit yang dibangun dari penurunan persamaan stokastik linier. Namun pada kenyataannya sering dijumpai berbagai keadaan ketika relasi pengukuran dari proses adalah nonlinier. Metode Kalman Filter pun mengalami perluasan menjadi suatu metode yang disebut Extended Kalman Filter. Metode ini akan dijelaskan lebih lanjut pada Bagian 2.

Ensemble Kalman Filter (EnKF) pertama kali diperkenalkan oleh G. Evensen pada tahun 1994 dalam pengimplementasian metode EKF untuk suatu model pada asimilasi data. Linierisasi dalam metode EKF ternyata menyebabkan kovariansi errornya membesar menuju tak-hingga sehingga Evensen telah memperkenalkan ide penggunaan sejumlah ensemble untuk mengestimasi kovariansi error pada tahap peramalan pada masalah yang sama [2]. Untuk alasan inilah EnKF dikembangkan. EnKF mewakili distribusi keadaan sistem dengan menggunakan kumpulan vektor keadaan, yang disebut ensemble, dan mengganti matriks kovariansi dengan sampel kovarians yang dihitung dari ensemble.

Pada paper ini akan dilakukan perbandingan pada ketiga metode diatas untuk pengaplikasian ke dalam model tingkat penyebaran virus HIV/AIDS yang dibangun oleh [3].

\section{Metode Estimasi}

\subsection{Kalman Filter}

Kalman Filter membahas masalah umum untuk memperkirakan keadaan proses waktu diskrit terkontrol yang diatur oleh persamaan linier stokastik:

$$
x_{k}=C x_{k-1}+D u_{k}+w_{k}
$$

pada waktu ke- $k$, dengan $x_{k-1}$ menyatakan vektor keadaan dan $u_{k}$ sebagai vektor dengan model pengukuran $z \in \Re^{m}$ yang mana

$$
z_{k}=H x_{k}+v_{k}
$$

Variabel acak $w_{k}$ dan $v_{k}$ menyatakan proses dan pengukuran noise. Masing-masing diasumsikan independen dan memiliki probabilitas distribusi normal. Dalam praktiknya, matriks kovarian noise dapat berubah pada setiap kali pengukuran, namun dalam hal ini noise diasumsikan konstan. $C, D$, dan $H$ masing-masing merupakan matriks-matriks yang elemennya adalah koefisien dari komponen masing-masing vektor.

Kalman Filter mengestimasi suatu proses dengan menggunakan suatu bentuk kontrol feedback yang berulang. Persamaan pada Kalman Filter dibagi dalam dua tahap yaitu persamaan pembaruan waktu (time update) dan persamaan pembaruan pengukuran (measurement update). 
Persamaan pembaharuan waktu yang ada akan digunakan untuk memproyeksikan (dalam waktu) keadaan saat ini dan estimasi kovarians errornya untuk mendapatkan estimasi priori untuk langkah selanjutnya. Selanjutnya persamaan pengukuran yang diperbarui akan digunakan untuk umpan balik, seperti halnya menggabungkan pengukuran baru ke dalam estimasi apriori untuk mendapatkan peningkatan estimasi priori. Persamaan pembaruan waktu juga dapat disebut sebagai prediksi, sedangkan persamaan pembaruan pengukuran sebagai koreksi.

Persamaan Kalman Filter untuk tahapan prediksi disajikan dalam persamaan (3) dan (4).

$$
\begin{aligned}
& \hat{x}_{k}^{-}=C \hat{x}_{k-1}+D u_{k} \\
& P_{k}^{-}=C P_{k-1}+C^{T}+Q
\end{aligned}
$$

dimana $\hat{x}_{k}^{-}$merupakan vektor prediksi dan $P_{k}^{-}$sebagai matriks kovarian prediksi.

Dari tahap prediksi, data hasil pengukuran awal akan digunakan untuk memprediksi variabel keadaan. Selanjutnya variabel keadaan yang diperoleh sebelumnya akan diperbaharui atau dikoreksi. Persamaan Kalman Filter untuk pembaruan pengukuran (koreksi) adalah sebagai berikut:

$$
K_{k}=P_{k}^{-} H^{T}\left(H P_{k}^{-} H^{T}+R\right)^{-1}
$$

Langkah pertama yang dilakukan adalah melakukan perhitungan Kalman gain, $K_{k}$. Selanjutnya dilakukan pembaruan prediksi dengan pengukuran $z_{k}$ :

$$
\hat{x}_{k}=\hat{x}_{k}^{-}+K_{k}\left(z_{k}-H \hat{x}_{k}^{-}\right)
$$

Kemudian dilakukan pembaruan kovarians error:

$$
P_{k}=\left(I-K_{k} H\right) P_{k}^{-}
$$

Variabel keadaan yang telah diperbaharui tersebut akan digunakan untuk prediksi pada kondisi selanjutnya. Proses tahapan tersebut akan dilakukan secara berulang sebanyak diskritisasi waktu yang diperlukan.

\subsection{Extended Kalman Filter}

Diasumsikan bahwa proses yang digunakan merupakan vektor keadaan $x \in \Re^{n}$, tetapi dalam prosesnya persamaan dibangun dengan penurunan persamaan stokastik non-linier

$$
x_{k}=f\left(x_{k-1}, u_{k}, w_{k}\right)
$$

dengan pengukuran $z \in \mathfrak{R}^{n}$ yang mana

$$
z_{k}=h\left(x_{k}, v_{k}\right)
$$

dimana variabel acak wk dan vk masing-masing merupakan proses dan pengukuran noise seperti pada persamaan (1) dan (2). Dalam hal ini fungsi non-linier $f$ dalam penurunan persamaan (8) berhubungan dengan keadaan pada tahap waktu sebelumnya $k-1$ kepada keadaan tiap satuan waktu $k$. Fungsi tersebut termasuk sebagai parameter yang mengarah kepada fungsi $u_{k}$ dan noise 
proses zero-mean $w_{k}$. Fungsi nonlinier $h$ pada persamaan pengukuran (9) berhubungan dengan keadaan $x_{k}$ kepada pengukuran $z_{k}$. Dalam praktiknya, tidak diketahui nilai masing-masing dari noise $v_{k}$ dan $w_{k}$ pada setiap tahapan. Namun, dapat diperkirakan keadaan dan vektor pengukuran tanpa memperhatikannya. Pada tahapan prediksi, pandang:

$$
\begin{aligned}
& x_{k}=f\left(x_{k-1}, u_{k}, 0\right) \\
& P_{k}^{-}=C_{k} P_{k-1} C_{k}^{T}+W_{k} Q_{k-1} W_{k}^{T}
\end{aligned}
$$

dimana $\hat{x}_{k}$ adalah suatu estimasi posteriori keadaan (dari tahap waktu $k$ sebelumnya). $C_{k}$ dan $W_{k}$ adalah proses Jacobian pada tahap $k$, dan $Q_{k}$ adalah proses persamaan kovarians error pada tahap $k$. Selanjutnya untuk tahapan pembaruan waktu (koreksi) dilakukan perhitungan Kalman gain, $K_{k}$ yaitu:

$$
K_{k}=P_{k}^{-} H_{k}^{T}\left(H P_{k}^{-} H^{T}+V_{k} R_{k} V_{k}\right)^{-1}
$$

Kemudian dilakukan pembaruan estimasi dengan pengukuran $z_{k}$ dan pembaruan kovarians error:

$$
\begin{array}{r}
\hat{x}_{k}=\hat{x}_{k}^{-}+K_{k}\left(z_{k}-h\left(\hat{x}_{k}^{-}, 0\right)\right) \\
P_{k}=\left(I-K_{k} H\right) P_{k}^{-}
\end{array}
$$

Sama seperti halnya pada Kalman Filter, variabel keadaan yang telah diperbaharui akan digunakan untuk prediksi pada kondisi selanjutnya. Proses tahapan tersebut akan dilakukan secara berulang sebanyak diskritisasi waktu yang diperlukan.

\subsection{Ensemble Kalman Filter}

Secara umum algoritma metode EnKF juga terdiri dari dua tahap yaitu tahap pembaruan waktu (prediksi) dan tahap pembaruan pengukuran (koreksi). Sebelum masuk ke tahap prediksi, terlebih dahulu dilakukan penghitungan terhadap dihitung mean ensemblenya. Algoritma EnKF dapat dilihat lebih jelas melalui Tabel 1.

\section{Didefinisikan}

$N_{\epsilon}$ : Banyaknya ensemble yang dibangkitkan

$x_{0, i}$ : Mean ensemble.

$\hat{x}_{k, i}^{-}$: Estimasi untuk tahap prediksi.

$\hat{x}_{k, i}$ : Estimasi untuk tahap koreksi. 
Tabel 1. Algoritma EnKF [4]

\begin{tabular}{|c|}
\hline Model Sistem dan Model Pengukuran \\
$x_{k+1}=f\left(x_{k}, u_{k}\right)+w_{k}$ \\
$z_{k}=H_{k} x_{k}+v_{k}$ \\
$w_{k} \sim N\left(0, Q_{k}\right) ; v_{k} \sim N\left(0, R_{k}\right)$ \\
\hline Inisialisasi \\
\hline Membangkitkan sejumlah $N_{\epsilon}$ ensemble : $x_{0, i}=x_{0}+w_{i}$ \\
Menentukan mean dari sejumlah $N_{\epsilon}$ ensemble : $\hat{x}_{0, i}=\frac{1}{N_{c}} \sum_{i=1}^{N_{c}} x_{0, i}$ \\
\hline Tahap Prediksi \\
\hline Estimasi : $\hat{x}_{k, i}^{-}=f\left(\hat{x}_{k-1, i}, u_{k-1, i}\right)+w_{k, i}$ \\
dengan mean estimasi : $\hat{x}_{k, i}^{-}=\frac{1}{N_{c}} \sum_{i=1}^{N_{c}} \hat{x}_{k, i}^{-}$ \\
\hline Kovariansi error : $P_{k+1}^{-}=\frac{1}{N_{c}-1} \sum_{i=1}^{N_{c}}\left(\hat{x}_{k, i}^{-}-\hat{x}_{k}^{-}\right)\left(\hat{x}_{k, i}^{-}-\hat{x}_{k}^{-}\right)^{T}$ \\
\hline Tahap Koreksi \\
\hline Membangkitkan $N_{\epsilon}$ data pengukuran : $z_{k, i}=z_{k}+v_{k, i}$ \\
Kalman gain : $K_{k}=P_{k}^{-} H^{T}\left(H P_{k}^{-} H^{T}+R_{k}\right)$ \\
Estimasi : $\hat{x}_{k, i}=\hat{x}_{k, i}^{-1}+K_{k}\left(z_{k, i}-H \hat{x}_{k, i}^{-}\right)$ \\
dengan mean : $\hat{x}_{k}=\frac{1}{N_{c}} \sum_{i=1}^{N_{\mathrm{c}}} \hat{x}_{k, i}$ \\
Kovariansi error : $P_{k}=\left[I-K_{k} H\right] P_{k}^{-}$ \\
\hline
\end{tabular}

\section{Model Matematika Penyebaran HIV/AIDS}

Model yang digunakan adalah model penyebaran virus HIV/AIDS pada Gay. Model ini dibangun berdasarkan interaksi antara individu rentan dan individu terinfeksi [3]. Model dibangun berdasarkan kompartemen SIR. Secara umum model penyebaran infeksi HIV/AIDS diberikan sebagai berikan:

$$
\begin{aligned}
& \frac{d S}{d t}=\varphi_{1}-S\left(\alpha_{1} \frac{I_{g}}{N}+\mu_{1}\right) \\
& \frac{d S_{g}}{d t}=\varphi_{2}-S_{g}\left(\alpha_{1} \frac{I_{g}}{N}+\mu_{1}\right) \\
& \frac{d I}{d t}=\alpha_{1} S \frac{I_{g}}{N}-I\left(\mu_{2}+\beta\right) \\
& \frac{d I_{g}}{d t}=\alpha_{1} S \frac{I_{g}}{N}-I_{g}\left(\mu_{2}+\beta\right) \\
& \frac{d A}{d t}=\beta I+\beta I_{g}-\mu_{2} A \\
& \qquad \frac{d N}{d t}=\frac{d S}{d t}+\frac{d S_{g}}{d t}+\frac{d I}{d t}+\frac{d I_{g}}{d t}+\frac{d A}{d t}
\end{aligned}
$$

dengan

$S=$ jumlah populasi individu rentan

$S_{g}=$ jumlah populasi individu gay rentan

$I=$ jumlah populasi individu normal terinfeksi 
$I_{g}=$ jumlah populasi individu gay terinfeksi

$A=$ jumlah populasi terinfeksi AIDS

$N=$ total jumlah populasi seluruh individu

$\varphi_{1}=$ tingkat perekrutan individu rentan normal

$\varphi_{2}=$ tingkat penginfeksian individu rentan gay

$\alpha_{!}=$tingkat penginfeksian individu normal oleh individu gay

$\alpha_{2}=$ tingkat penginfeksian antar populasi gay

$\beta=$ tingkat perpindahan individu terinfeksi menjadi AIDS

$\mu_{1}=$ tingkat kematian pada kelompok rentan

$\mu_{2}=$ tingkat kematian pada kelompok yang terinfeksi

Pada persamaan model, akan digunakan nilai-nilai parameter seperti yang tertera pada Tabel 2.

Tabel 2. Nilai awal untuk tiap Subpopulasi [3]

\begin{tabular}{|c|c|}
\hline Parameter Komputasi & Nilai \\
\hline$S(0)$ & 104.811 \\
\hline$S_{g}(0)$ & 631 \\
\hline$I(0)$ & 296 \\
\hline$I_{g}(0)$ & 432 \\
\hline$A(0)$ & 100 \\
\hline
\end{tabular}

Tabel 3. Parameter Komputasi [3]

\begin{tabular}{|c|c|}
\hline Parameter & Nilai \\
\hline$\varphi_{1}$ & 63 \\
\hline$\varphi_{2}$ & 3081 \\
\hline$\alpha_{1}$ & 0,95 \\
\hline$\alpha_{2}$ & 2,85 \\
\hline$\beta$ & 0,06 \\
\hline$\mu_{1}$ & 0,00267 \\
\hline$\mu_{2}$ & 0,3333 \\
\hline
\end{tabular}

Selanjutnya akan dilakukan simulasi dengan program MATLAB. Adapun pada paper ini simulasi perbandingan yang dilakukan adalah menggunakan Program MATLAB 2013a. 


\section{$4 \quad$ Hasil dan Pembahasan}

Sebelum melakukan simulasi, hal yang perlu diperhatikan adalah bahwa persamaan diatas adalah bentuk persamaan non-linear. Metode Kalman Filter sendiri bersifat linier, sedangkan untuk Extended Kalman Filter merupakan estimasi bersifat non-linier. Sehingga diperlukan adanya linierisasi dengan menggunakan matriks Jacobian. Selain itu perlu juga dilakukan adanya diskritisasi. Diskritisasi sendiri bertujuan untuk mendapatkan bentuk persamaan dalam keadaan diskrit. Hal ini dikarenakan metode KF, EKF, EnKF merupakan model sistem yang menggunakan pengukuran dan model sistem waktu diskrit. Sehingga dalam hal ini akan terlebih dahulu dilakukan pendiskritan terhadap model matematika.

Persamaan-persamaan (15) - (19) yang merupakan sistem orde satu yang selanjutnya akan didiskritisasi. Diskritisasi dilakukan untuk mendapatkan bentuk matriks $A$ yang selanjutnya diaplikasikan metode estimasi KF, EKF dan EnKF. Secara umum, Penerapan beda maju terhadap $\frac{\partial_{u}}{\partial_{t}}$ di titik $k$, diperoleh

$$
\frac{\partial_{u}}{\partial_{t}}=\frac{u_{k+1}-u_{k}}{\Delta t}
$$

sehingga hasil diskritisasi dari sistem orde satu diperoleh persamaan berikut:

$$
\begin{gathered}
S(k+1)=S(k)-\left(\varphi_{1}-S(k)\left(\alpha_{1} \frac{I(k)}{\mu}+\mu_{1}\right)\right) d t \\
S_{g}(k+1)=S(k)-\left(\varphi_{2}-S(k)\left(\alpha_{1} \frac{I_{g}(k)}{\mu}+\mu_{1}\right)\right) d t \\
I(k+1)=I(k)-\left(\alpha_{1}-S(k) \frac{I_{g}(k)}{\mu}-I(k)\left(\mu_{2}+\beta\right) d t\right. \\
I_{g}(k+1)=I_{g}(k)-\left(\alpha_{1}-S(k) \frac{I_{g}(k)}{\mu}-I_{g}(k)\left(\mu_{2}+\beta\right) d t\right. \\
A(k+1)=A(k)-\beta I(k)+\beta I_{g}(k)-\mu_{2} A(k) d t
\end{gathered}
$$

Selanjutnya, diperoleh matriks A yang digunakan untuk estimasi dengan KF, EKF, dan EnKF berdasarkan matriks Jacobian yang dibentuk dari persamaan-persamaan sebelumnya.
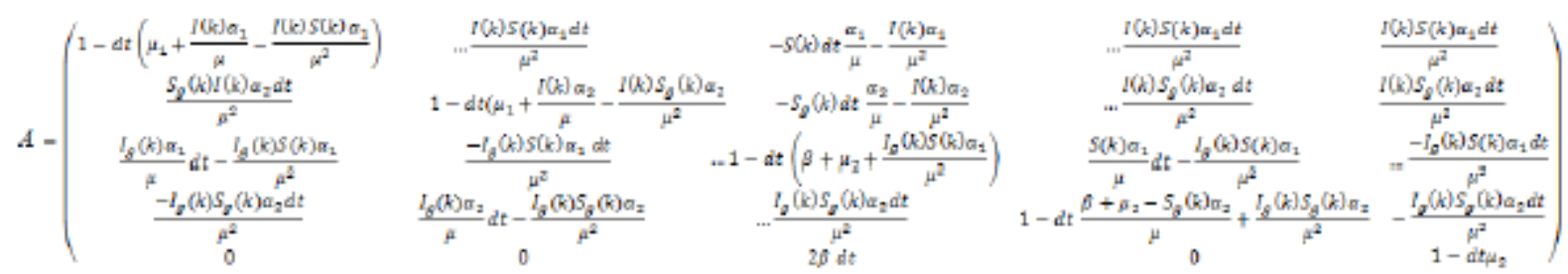

Dalam simulasi akan digunakan matriks $A$ yang diperoleh dengan matriks Jacobian. Hasil dari simulasi akan disajikan dalam dua cara yaitu dengan hasil angka pada tabel dan grafik. Dalam 
simulasi dipilih dua keadaan. Pertama keadaan ketika nilai $Q<1$ dan ketika $Q>1$. Dalam penyajian hasil pada tabel dipilih keadaan untuk $Q$ sekecil mungkin, dimana $Q<1$, dengan demikian $P_{0}=Q_{0}=R_{0}=10^{-2} . I_{5 \times 5}$ eig $=\operatorname{rand}(5,1)$, dan nilai iterasi $T=1000$. Disini diberikan banyaknya nilai untuk membangkitkan ensemble berbeda-beda yaitu $N_{\epsilon}=10,100$, dan 200, hal ini dilakukan karena adanya nilai matriks yang random, sehingga hal ini perlu dilakukan untuk melihat perbandingan hasil nilai kemudian. Sedangkan pada gambar, kedua keadaan disajikan. Hal ini dilakukan untuk melihat pengaruh $Q$, juga $P$ pada perbandingan hasil yang diberikan.

Pertama-tama dilihat hasil yang disajikan dalam tabel, dengan masing-masing nilai iterasi, dan metode yang diberikan berbeda-beda:

Tabel 4. Hasil simulasi untuk nilai Ensemble $\left(N_{\epsilon}\right)$ berbeda pada EnKF

\begin{tabular}{|c|c|c|c|c|}
\hline$N$ & State & Simulasi 1 & Simulasi 2 & Simulasi 3 \\
\hline \multirow[t]{5}{*}{10} & $S$ & 4.4504 & 0.8807 & 1.4869 \\
\hline & $S_{g}$ & 2.0625 & 0.4549 & 0.6564 \\
\hline & $I$ & 1.0669 & 0.2570 & 0.3608 \\
\hline & $I_{g}$ & 1.0695 & 0.2545 & 0.3620 \\
\hline & $A$ & 1.1389 & 0.4309 & 0.5769 \\
\hline \multirow[t]{5}{*}{100} & $S$ & 0.8370 & 0.7018 & 1.3365 \\
\hline & $S_{g}$ & 0.3266 & 0.3006 & 0.3447 \\
\hline & $I$ & 0.1804 & 0.1539 & 0.1854 \\
\hline & $I_{g}$ & 0.1773 & 0.1537 & 0.1811 \\
\hline & $A$ & 0.2329 & 0.2370 & 0.2426 \\
\hline \multirow[t]{5}{*}{200} & $S$ & 0.7447 & 0.6158 & 1.3283 \\
\hline & $S_{g}$ & 0.2985 & 0.2916 & 0.3612 \\
\hline & $I$ & 0.1655 & 0.1614 & 0.1665 \\
\hline & $I_{g}$ & 0.1680 & 0.1543 & 0.1659 \\
\hline & $A$ & 0.2042 & 0.2118 & 0.2165 \\
\hline
\end{tabular}

Dari Tabel 4 dapat dilihat bagaimana nilai ensemble $(N)$ memberikan pengaruh pada nilai estimasi. Dapat terlihat bahwa dari seluruh hasil, ketika nilai $N$ semakin besar maka nilai estimasi EnKF untuk tiap persamaan justru semakin kecil. Dari sini dapat dilihat bahwa semakin besar nilai ensemble yang diberikan maka semakin mendekati nilai state.

Dalam memberikan suatu estimasi, tentu saja tebakan yang ada tidak akan sempurna, tetapi memuat noise. Dapat terjadi ketika kemungkinan seseorang memberikan suatu estimasi yang terlalu besar atau estimasi yang terlalu kecil. Seperti yang telah disebutkan sebelumnya, pada 
simulasi perbandingan dengan gambar grafik, akan dilakukan perbandingan dengan memberikan dua keadaan pada kovarians error $\operatorname{sistem}(Q)$, yaitu ketika $Q>1$ dan $Q<1$. Pemberian nilai estimasi yang sesuai dapat bergantung pada tingkat kemampuan dan pengetahuan pemberi estimasi terhadap hal yang akan di estimasi. Selanjutnya untuk nilai $P$ dan $R$ masing-masing akan mengikuti asumsi yang sudah diberikan sebelumnya yaitu $P_{0}=Q_{0}=R_{0}$. Gambar grafik perbandingan hasil metode KF, EKF, dan EnKF pada tiga persamaan yang berbeda dapat terlihat pada Gambar 1-10.

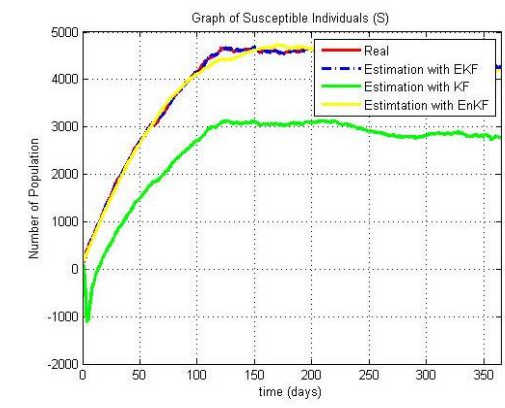

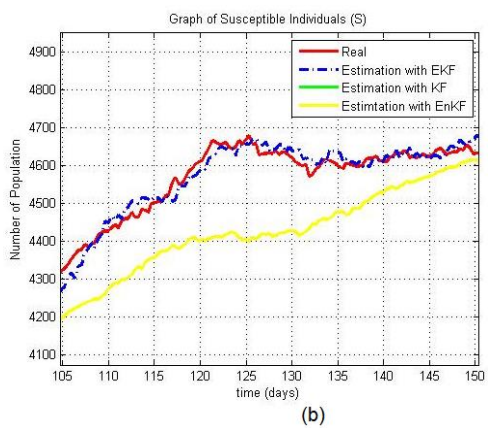

Gambar 1. (a) Grafik tingkat individu normal yang rentan $(S)$ untuk $Q>1$

(b) Grafik dilihat secara dekat
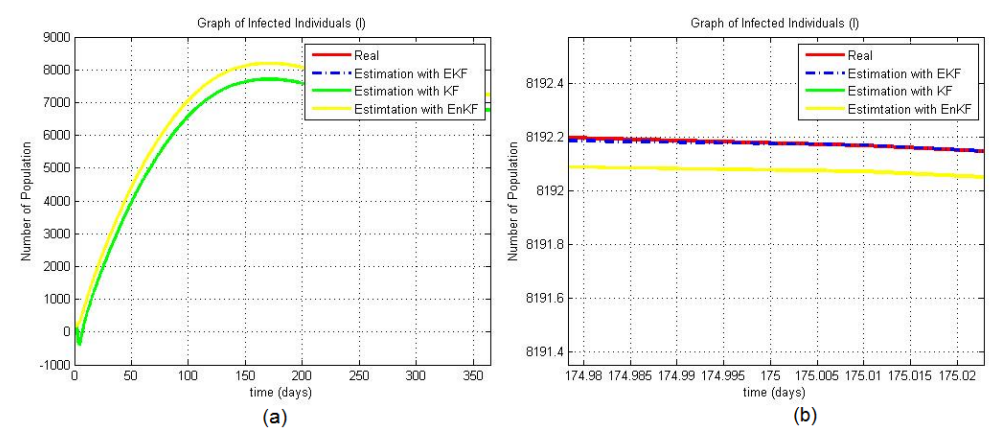

Gambar 2 (a) Grafik tingkat individu normal yang rentan $(S)$ untuk $Q<1$

(b) Grafik dilihat secara dekat
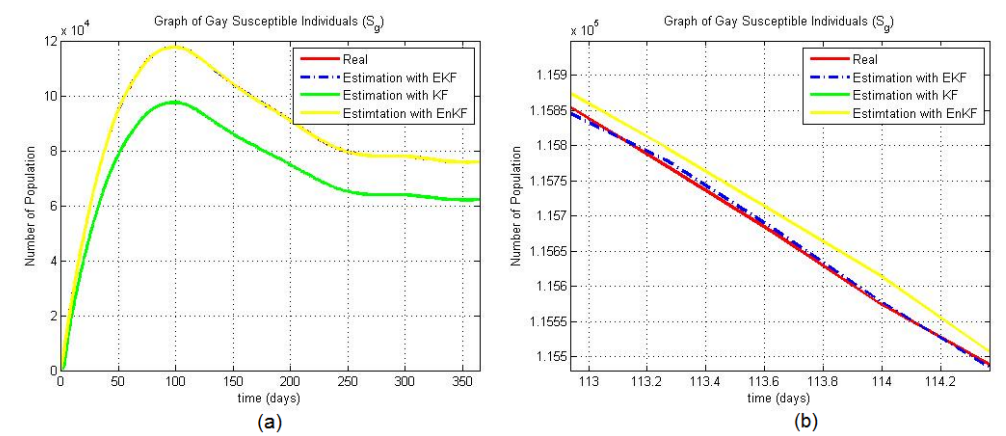

Gambar 3 (a) Grafik tingkat individu gay yang rentan $\left(S_{g}\right)$ untuk $Q>1$

(b) Grafik dilihat secara dekat 

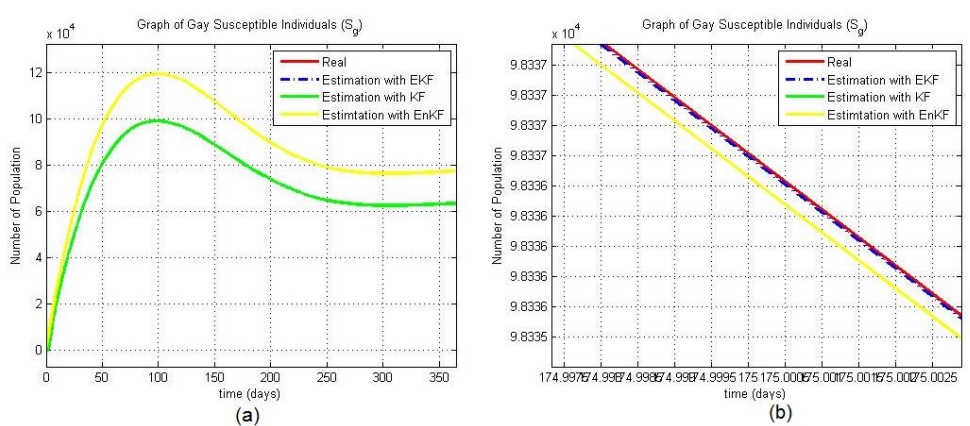

Gambar 4 (a) Grafik tingkat individu gay yang rentan $\left(S_{g}\right)$ untuk $Q<1$

(b) Grafik dilihat secara dekat
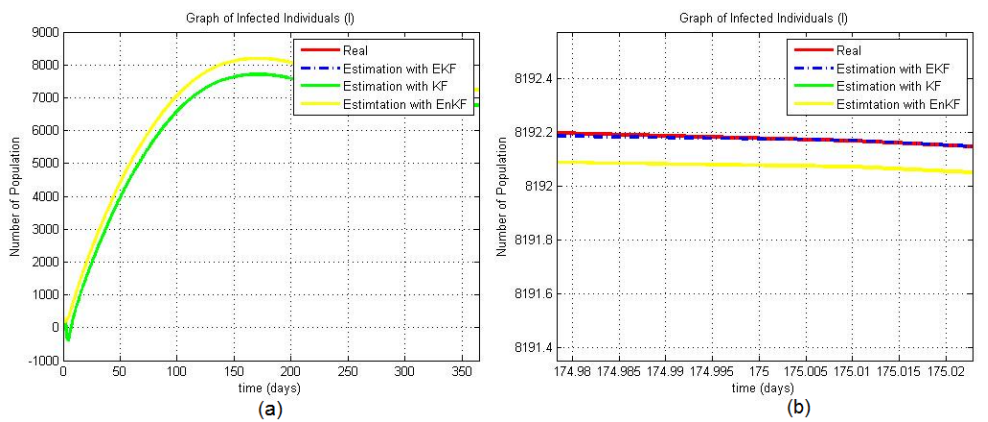

Gambar 5 (a) Grafik individu normal yang terinfeksi $(I)$ untuk $Q>1$

(b) Grafik dilihat secara dekat

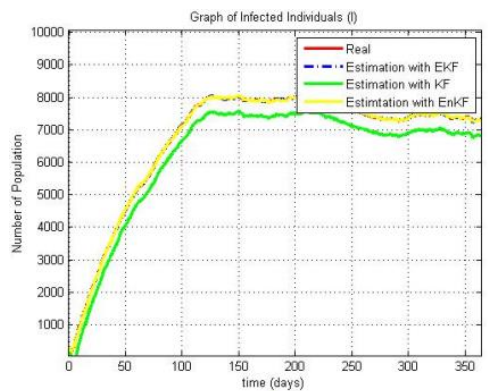

(a)

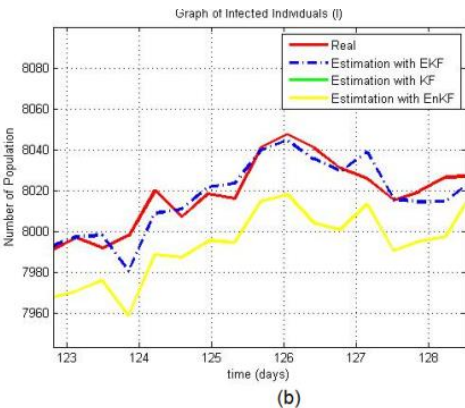

(b)

Gambar 6 (a) Grafik individu normal yang terinfeksi (I) untuk $Q<1$

(b) Grafik dilihat secara dekat 


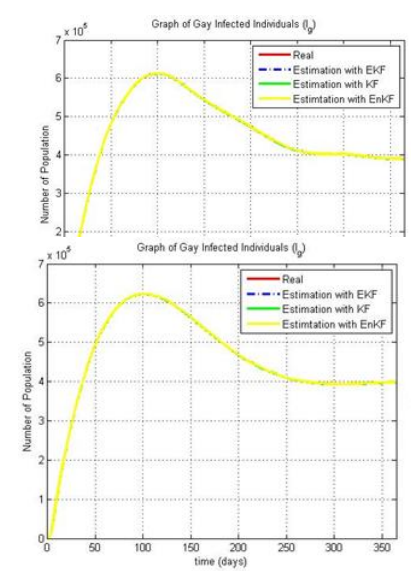

(a)

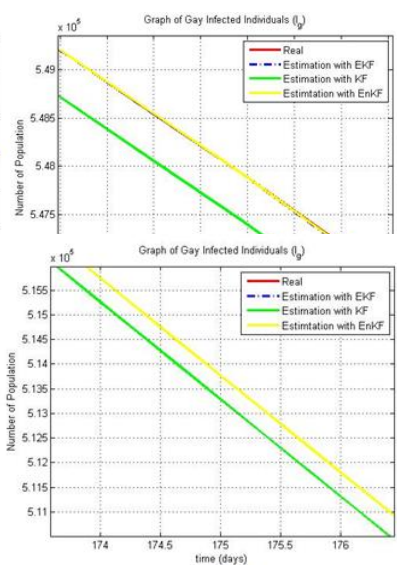

(b)

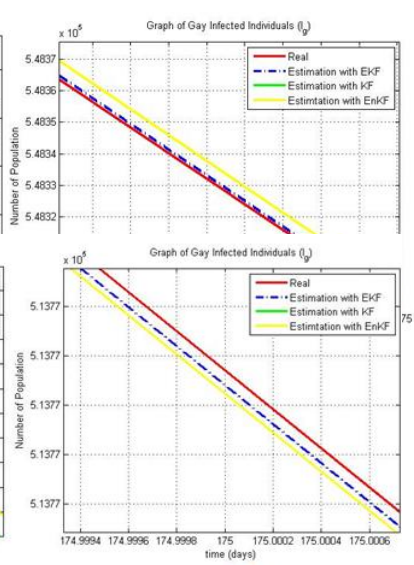

(c)

Gambar 7 (a) Grafik tingkat individu gay yang terinfeksi $\left(I_{g}\right)$ untuk $Q>1$ (b) dan (c) Grafik dilihat secara dekat

Gambar 8 (a) Grafik tingkat individu gay yang terinfeksi $\left(I_{g}\right)$ untuk $Q<1$ (b) dan (c) Grafik dilihat secara dekat.

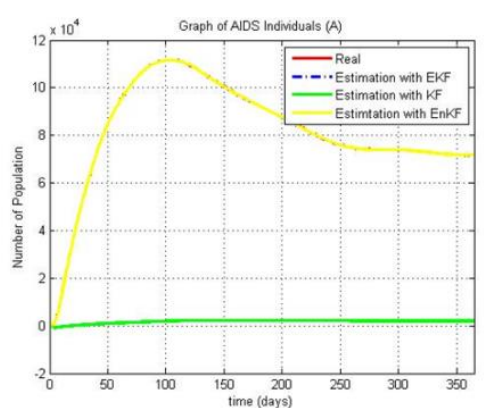

(a)

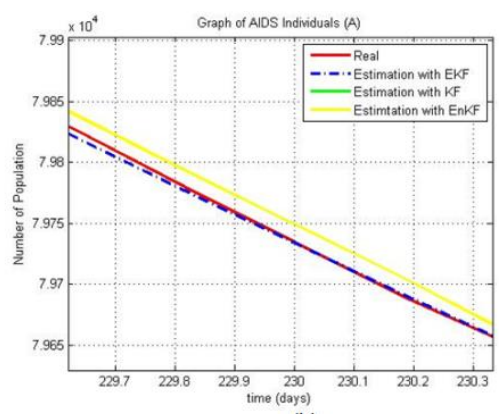

(b)

Gambar 9 (a) Grafik tingkat penyebaran virus AIDS (A) untuk $Q>1$

(b) Grafik dilihat secara dekat 


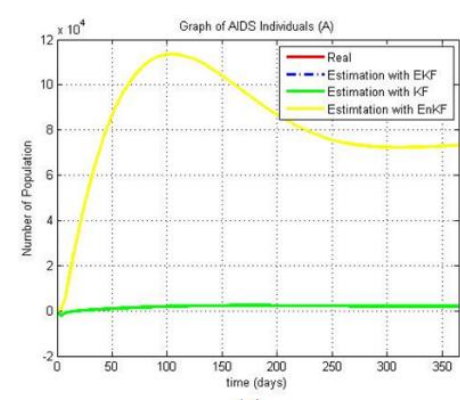

(a)

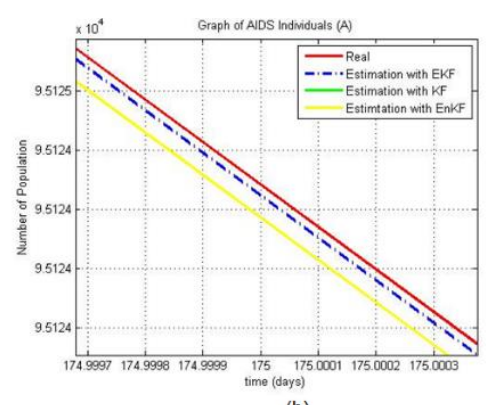

(b)

Gambar 10 (a) Grafik tingkat penyebaran virus AIDS (A) untuk $Q<1$

(b) Grafik dilihat secara dekat

Gambar 1 dan 2 menunjukkan bahwa estimator terbaik bagi $S$ adalah EKF karena nilai yang dihasilkan mendekati dengan nilai real sedangkan EnKF memberikan nilai estimasi yang cukup bagus namun masih berada di bawah EKF. Pada Gambar 3-10 juga tampak bahwa metode Extended Kalman Filter lebih baik dibandingkan metode lainnya. Sedangkan hasil yang diberikan oleh KF tidak sebaik dari kedua estimator tersebut. Adapun untuk $S_{g} I, I_{g}$ maupun $A$ hasil yang diberikan oleh estimator EKF lebih baik dibandingkan dengan estimator EnKF maupun KF.

\section{Simpulan}

Berdasarkan hasil simulasi program MATLAB didapatkan beberapa kesimpulan, diantaranya:

- Pemberian pembangkitan nilai ensemble $N_{\epsilon}$ pada metode EnKF akan mempengaruhi baik buruknya nilai estimasi. Untuk nilai $N$ yang semakin besar, waktu running program yang diperlukan juga semakin lama.

- Pemberian nilai $P$ (Inisialisasi awal), $Q$ (kovarian error sistem), dan $R$ (kovarian error pengukuran) akan sangat berpengaruh pada hasil estimasi.

- Metode estimasi yang terbaik untuk seluruh persamaan, $S, S g$, I, Ig, dan $A$ adalah metode Extended Kalman Filter (EKF). Hal ini sangat dimungkinkan, karena EKF merupakan metode pengembangan KF untuk estimasi persamaan non-linier, yang sesuai dengan persamaan yang kita gunakan pada paper ini.

- Pemberian nilai $P$ dan $Q$ yang tepat memberikan pengaruh pada semakin baiknya nilai estimasi yang akan didapatkan. Untuk persamaan pertumbuhan populasi virus HIV/AIDS yang digunakan pada paper ini, estimasi EKF dengan nilai $Q>1$ memberikan hasil yang relatif lebih mendekati nilai real dibandingkan untuk keadaan ketika $Q<10$. Hal ini 
terlihat dari besarnya jarak yang terlihat antara pada beberapa grafik seperti pada persamaan $I_{g}$ dan $A$ untuk $Q<1$.

- Estimasi yang paling buruk atau memberikan nilai paling jauh adalah estimasi dengan metode Kalman Filter (KF), hal ini terjadi karena KF merupakan estimasi untuk persamaan linier.

\section{Daftar Pustaka}

[1] M. Grewal and A. Andrews, Kalman filtering: theory and practice using MATLAB, vol. 5. 2011.

[2] K. D. Purnomo and E. Apriliani, "Estimasi Populasi Plankton dengan Ensemble Kalman Filter Estimation of Plankton Population Using Ensemble Kalman Filter,” pp. 38-44, 1994.

[3] R. Setiawaty, R. Ratianingsih, and A. I. Jaya, "Analisis Kestabilan pada Model Penyebaran HIV / AIDS," vol. 10, no. 1, pp. 74-82, 2013.

[4] E. Apriliani, Subchan, F. Yunaini, and S. Hartini, Estimation and control design of mobile robot position, vol. 77 , no. 1. 2013. 